\title{
A ANTROPOLOGIA DA GLOBALIZAÇÃO E A GLOBALIZAÇÃO DA ANTROPOLOGIA
}

\author{
ABÉLÈS, Marc \\ Anthropologie de la globalisation. \\ Paris: Payot, 2008, 280 p.
}

POR

Celso de Brito ${ }^{1}$

\begin{abstract}
$\mathrm{E}$ ntre outros atributos da trajetória acadêmica de Marc Abélès, destaco os cargos de professor diretor da cadeira de Antropologia das Instituições, na EHESS e o de diretor do Centro-Franco-Argentino des Hautes Études de Buenos Aires. Tendo iniciado sua trajetória acadêmica com um estudo sobre as práticas políticas em uma pequena localidade da Etiópia chamada de Ochollo, sob a orientação de Claude LéviStrauss, Abélès se aproximou da temática da globalização paulatinamente: de Ochollo para a vida política da região de Borgonha na França, para a Assembléia Nacional Francesa, passando pela abordagem transnacional da Comissão e do Parlamento europeus e - findando na obra que ora resenho - mobilizando toda essa experiência na elaboração de uma abordagem acerca da vida política no planeta.

Anthropologie de la Globalisation é estruturado em cinco capítulos que refletem a articulação da Antropologia com as disciplinas de Economia e Política, e tratam de temas como violência, migração, cidadania e soberania, tudo, evidentemente, subordinado ao tema central: o fenômeno da globalização. Trata-se de um livro repleto de referências aos autores clássicos e contemporâneos tornando-o interessante tanto para antropólogos experientes, quanto para neófitos.
\end{abstract}

\footnotetext{
${ }^{1}$ Doutorando do Programa de Pós-Graduação em Antropologia Social, Universidade Federal do Rio Grande do Sul, Brasil. celsodebrito@yahoo.com.br
} 
Abélès inicia sua discussão ao introduzir sua preferência pelo termo "globalisation" em detrimento do termo frequentemente utilizado na Antropologia francófona, "mondialisation", para evidenciar a diferença existente entre as imbricações e relações sociais mantidas em escala planetária já ocorridas em outros períodos históricos e o fenômeno contemporâneo que se compromete a elucidar.

Ao revisar os clássicos da Antropologia, o autor assume uma postura crítica em relação às análises sociais que privilegiam abordagens microssociais, de campos localizados e exóticos, afirmando a importância de uma Antropologia da vida social cotidiana articulada com questões macrossociais relacionadas às distintas formas de pertencimento global.

Em sua argumentação Abélès atribui os devidos méritos aos economistas, já que foram eles os primeiros a reconhecer as mudanças relativas ao fenômeno "globalização" na década de 1980, tanto acerca da descentralização do acúmulo de capital, quanto da sua flexibilização. Ao considerar o enfraquecimento de fronteiras nacionais e o surgimento/fortalecimento de instituições internacionais, Abélés toma as representações dos indivíduos acerca do poder e do estado não como uma consequência desta configuração política, mas sim como uma de suas causas. Eis uma interpretação interessante do ponto de vista antropológico. A globalização marcaria, então, um período de "reordenamento dos princípios da vida social assim como da ordem do mundo" (p. 22).

Em um contexto como este, diz Abélès: "0 pesquisador/observador não pode deixar de analisar três elementos complementares: a influência das forças externas sobre a vida local, as conexões existentes entre diferentes lugares e as representações que moldam o cotidiano e que se alimentam do global" (p.94).

Como consequência deste novo ordenamento social o antropólogo apresenta-se como um cidadão atuante na sociedade, assim como seus interlocutores se apresentam como observadores e descritores da realidade, ambos articulando argumentos em prol de seus posicionamentos de formas semelhantes. Aqui Abélès responde às inquietações de certa antropologia pós-moderna sem excluir, contudo, o papel atribuído ao antropólogo de "orquestrar" o seu trabalho.

A Antropologia da globalização defendida por Abélès se afirma como uma Antropologia crítica, não porque se identifica com o discurso de compaixão humanitária, mas sim porque desenha um espaço de interlocução entre as etnografias de origens diversas ou multissituadas, como diria Marcus, deixando de privilegiar 0 estudo do exótico e dos marginais para "constituir o próximo em objeto aberto à interlocução etnográfica" (p. 105). Partindo desta perspectiva, um dos objetos de estudo antropológico privilegiados pelo autor é o estado-nação. Trata-se de desnaturalizar as formas de poder tradicionais de modo que seja possível reconhecer um novo tipo de 
ordenamento global, no qual a unidade política estado-nação se encontra destituída do poder que detinha há algumas décadas. 0 poder é analisado por Abélès a partir do cotidiano da vida social articulado à esfera simbólica, de modo que sua proposição caraceriza-se pela multidisciplinaridade na qual a dialética do político e do cultural representa uma renovação antropológica na medida em que reconhece as contribuições específicas das disciplinas Ciência Política e Sociologia das Instituições.

Dois conceitos são inaugurados neste livro: "convivência" e "sobrevivência". A ideia de "convivência" estaria relacionada à tradição política de um quadro nacional pautado na busca pela harmonia entre sujeitos pertencentes a um mesmo território. Atualmente impera, segundo Abélès, a consciência de que 0 risco esteja superando a imagem de segurança harmônica de um estado-nação, o que reconfigura a relação entre indivíduo e política fazendo da noção de "sobrevivência" uma ferramenta analítica indispensável na medida em que permite 0 reconhecimento do enfraquecimento do poder do estado nas representações dos indivíduos.

Uma análise deste gênero possibilita relativizar possíveis posicionamentos taxativos quanto à falência ou não do estado-nação, justamente ao apontar que é a relação imediata entre a ideia de estado-nação e o território que se desfaz. Esta nova configuração corresponde à crescente importância de instituições internacionais e 0NG's que, ao buscarem representar os interesses de indivíduos e coletivos de diferentes localidades, finda por minar a soberania nacional.

Enquanto o estado propõe uma "política de convivência" que não corresponde às expectativas dos indivíduos, as instituições internacionais e ONG's defendem questões voltadas à "política da sobrevivência". Essa política teria alçado tamanha relevância devido às novas formas de violência que caracterizariam a atual organização mundial na qual o estado não detém o seu monopólio. A globalização geraria, ao lado de riqueza e desigualdades gritantes, sujeitos excluídos da vida política e inseridos na violência: os chamados homo sacer de Aganbem, que não teriam nada além do que sua "vida nua". Como é o caso dos sujeitos descritos por Scheper-Hughes (2009), que não possuem nada além de seus próprios órgãos corporais para negociar no mercado internacional.

Abélès dialoga com autores que acreditam que a construção da cidadania seja parte do processo de subjetivação, enquanto projeto biopolítico utilizado pelo estado para assegurar o consentimento à ordem estabelecida. Ele prefere entender tal processo atribuindo agência aos indivíduos que negociariam suas próprias cidadanias. Aihwa Ong chama atenção ao permanente jogo em que sujeitos potencialmente marginais manipulam alguns elementos da chamada "modernidade" ou do "liberalismo" em seu proveito obtendo "cidadanias flexíveis". Por exemplo, chineses que obtém vistos de estudos nos Estados Unidos que, uma vez fixados no país, mobilizam suas redes sociais 
possibilitando a entrada de novos imigrantes oferecendo, consequentemente, mão-deobra barata ao país.

Abélés remete esta discussão sobre cidadania à questão do estado-nação e seu poder. Ao analisar as possibilidades de negociação pela cidadania a partir de uma abordagem etnográfica o autor percebe que apesar do fato de que os indivíduos tenham certa agência, a ideia de cidadania continua tributária da ideia de soberania nacional. Dessa forma, em tempos de globalização, a cidadania para alguns sujeitos não pode ser mais do que flexível e a outros tantos impossível. Logo, tanto o estado como a cidadania por ele apregoada não seriam suficientes para garantir direitos aos sujeitos globalizados.

Assim, as ONGs aparecem em etnografias como alternativa para a aquisição de tais direitos. Tomando como referência as filosofias clássica e iluminista, Abélès analisa o conceito de "sociedade civil" visando melhor entender o fenômeno das Organizações Não Governamentais. Para 0 autor, "sociedade civil" é definida em sua ambiguidade, ou seja, guarda certa autonomia em relação ao estado e, ainda assim, organiza-se em relação a ele, sendo instrumentalizada ora contra, ora a favor da ordem instituída.

Nas últimas décadas, diz Abélès, as novas configurações de violência têm feito surgir ONG's de cunho humanitário que agem sem a intervenção de poderes estatais. 0 termo "humanitário" desta sentença seria decorrência do impulso para a "política da sobrevivência" que orientaria este movimento à revelia da "política de convivência" mantida pela organização política tradicional do estado-nação.

Abélès explicita o debate entre os prós e os contra ONG's e se posiciona, por fim, dizendo que estas novas organizações têm sua importância internacional no fato de que não restringem suas pautas com base em relações diplomáticas entre nações, de modo que fazem emergir questões urgentes dos sujeitos marginalizados e destituídos de voz na esfera pública. As ONG's manteriam, segundo Abélès, uma articulação com a esfera econômica globalizada e, por isso, não se ateria às esferas nacionais, já que sua ação tem repercussões no espaço público e assim acaba por afetar o consumo. Haveria, então, no fenômeno das ONG's uma complementariedade entre a "economia de mercado" que gera desigualdades e a "economia da sobrevivência", ou seja, as ONG's são vistas como realmente ambíguas neste processo.

Mais do que uma Antropologia da política, Abélès expõe sua compreensão acerca de uma Antropologia que acredita ser verdadeiramente política: descrever a realidade em sua incoerência e desordem, integrando e fricçionando distintos saberes. Assim, mais do que uma disciplina isolada a "Antropologia da Globalização" reflete o seu objeto na medida em que se constitui a revelia de fronteiras e barreiras disciplinares. Nesse sentido, Anthropologie de la Globalisation sugere uma globalização da própria Antropologia. 